\title{
ASSESSING TOURIST SATISFACTION IN THE AZORES: A MICROECONOMETRIC APPROACH
}

\author{
António Gomes de Menezes ${ }^{\mathrm{a}}{ }^{*}$, José Cabral Vieira ${ }^{\mathrm{b}}$ \\ and Jeana Carvalho ${ }^{c}$
}

${ }^{a}$ University of the Azores and CEEAplA, Rua Mãe de Deus, 9500 Ponta Delgada, Portugal, e-mail: menezesa@uac.pt

${ }^{\mathrm{b}}$ University of the Azores and CEEAplA, Rua Mãe de Deus, 9500 Ponta Delgada, Portugal, e-mail: josevieira@uac.pt

${ }^{\mathrm{c}}$ Grupo SATA

${ }^{*}$ Corresponding author

\begin{abstract}
This paper uses a new micro-survey on a representative sample of tourists who visited the Azores, an emerging Portuguese Archipelago tourist destination, to quantify the determinants of tourist satisfaction, the intention to revisit the destination and the likelihood of recommending the destination to friends and relatives. To do so we employ a microeconometric ordered probit model. The econometric results are statistically valid and economically important, since they uncover significant and heterogeneous responses which vary according to the tourists' socio-demographic profiles, as well as trip attributes, among other factors. Our results allow policymakers and tourism economic agents alike to tailor policies aimed at increasing tourist satisfaction, repeat visitation rates and recommendation rates.
\end{abstract}

Key words: Azores, tourist satisfaction, microeconometric probit model

\section{Introduction}

The tourism sector has experienced significant growth in the Azores, whose aim to acquire worldwide tourist destination status. The Regional Government has promoted and supported growth enhancing policies of regional tourism supply as well as creating initiatives towards building awareness of the Region as a tourism destination in different tourism markets especially Western Europe and North America. As a result the number of international and domestic tourists has grown; from 1995 to 2005 it grew from 159,000 to 260,000 (SREA).

Tourism is an expanding economic sector in the Azores. However it is still in an embryonic stage despite being seen as one of the few sectors with capacity to enlarge and diversify the Azores' export-driven economy, along with integrating a significant part of the female workforce. New tourist destinations continually arise worldwide, increasing competition. Part of the success in reaching a tourism worldwide destination status is through the tourists' assessment about the destination. 
This is the purpose of this study: in the Azores little is known about tourists' assessment. In the international tourism sector, the Azores are an emergent destination, little known, and therefore tourist services here have not fully developed. To do so is necessary to increase the quality of tourist supply. One way to gauge quality is through tourists' satisfaction, as measured in this study.

Menezes, Moniz and Vieira (2008) refer that studies in the area of tourism may offer valuable tools to private operators and to the policymakers in the field, as the studies may uncover which individual socio-demographic profiles and trip attributes promote longer stays of tourists and, therefore, aid the design of more effective promotional campaigns of the Region.

This study presents new evidence from a new survey of the satisfaction of tourists who visit the Azores, and employs a microeconometric ordered probit model to enable policymakers a statistically valid and economically significant interpretation of the quality of the tourists' experiences in the Azores.

This paper is organized in five sections. The following section presents the characterization of tourism in the Autonomous Region of the Azores. Section three reviews the literature. Section four presents the econometric model which analyzes four indicators: tourist satisfaction; satisfaction with the visit when compared with expectations; intention of revisiting the Azores; and the likelihood of recommending this tourist destination to friends and relatives. Finally, section five presents main conclusions, limitations and future developments.

\section{Tourism in the Azores}

The Archipelago of the Azores, or The Azores, are a Portuguese archipelago consisting of nine islands (from $17 \mathrm{~km}^{2}$ - Corvo - to $747 \mathrm{~km}^{2}$ - São Miguel), spread between $36^{\circ}-43^{\circ} \mathrm{N}, 25^{\circ}-31^{\circ} \mathrm{W}, 1564 \mathrm{~km}$ west of Lisbon and 2,300 km east of Nova Scotia, a land area of $2,333 \mathrm{~km}^{2}$.

The Azores's population in 1997 was 243760, distributed in the nine islands. In 2006 it was 243016, with the most populated island of the archipelago being São Miguel (132671), followed by Terceira with 55697 inhabitants. The least populated island was Corvo with 468 inhabitants.

The islands have diversified landscape, and a rich environment, natural and cultural heritage. The Azores are a true heaven for nature lovers and for active tourism seekers. The existing supply in terms of golf, whale watching, pedestrian tracks, big game fishing, scuba-diving, as well as the quality of its accommodation units along with the Rural Tourism Accommodation, and facilities for tourism of congress and cruises provide an unforgettable holiday. The tea plantations and cigar processing, the unique lagoons, the gastronomy, the kindness of its people, or the volcanism, are just some of the features that turn the Azores a unique destination. 


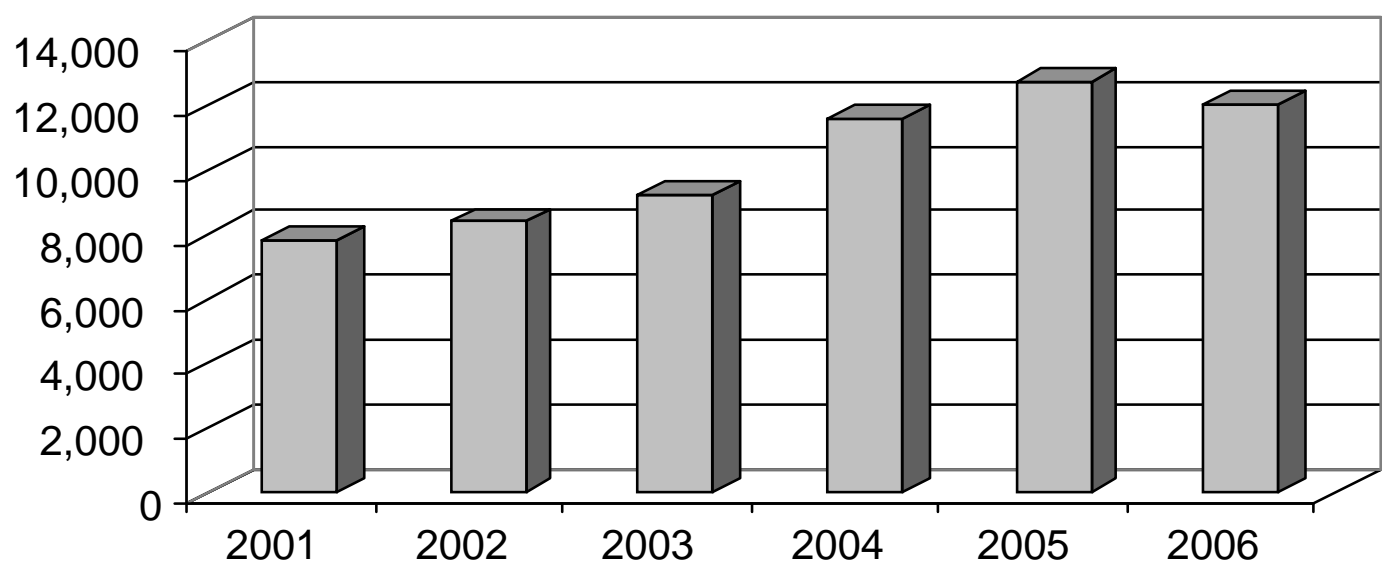

Source: Serviço Regional de Estatística dos Açores

Figure 1 Number of beds in the Autonomous Region of the Azores

The tourism sector has experienced significant growth regarding supply represented by the number of hotels. The accommodation capacity has increased from 4507 beds in 2001 to 8239 in 2006 (see Figure 1). Between 2003 and 2007 overnight stays grew by $47,3 \%$, reaching around 1.2 million overnights in 2007, whereas the occupation rate went from $37,4 \%$ to $40 \%$, and total income rose $45,8 \%$ to 55 million EUR in 2007.

\section{Literature Review}

Tourism starts with the wish of people to travel and it should end with people's satisfaction towards the trip. This way one of the major objectives of tourist planning of a certain region or local must be the visitants' satisfaction (Gunn, 1993).

In an assertive vision of quality of tourism (or in any other relation between supplier and customer), the main concern must be to render a service that corresponds to the customers' expectations conceived based on the destination image (regarding the different components of the tourist product) and on the trip's cost. Thus, we have here the difference between substantial or subjective quality (on the supplier's optic) and the quality perceived by the client (real and subjective) that not always match (Batista, 1997).

Valle et al. (2006) define satisfaction as the tourist's emotional state after his holiday trip. Flecha and Damiani (2006) refer that satisfaction is the level of the tourist's feeling regarding performance (or result) of a holiday destination regarding his expectations. This feeling of satisfaction will increase the probability of the tourist revisit the same destination, give favourable critics about the visited destination and create a positive image (Fernandez and Picos, 2005). Andreassen and Lindestad (1998) 
refer that in the present markets, where the differences between products are minimal or inexistent, and the capacity of maintaining the clients' fidelity (tourists) is determinant.

Currently, competition between different tourist destinations is fierce. This way it's essential that each tourist destination create a strong and competitive image enabling to draw attention from tourists (Marino, 2007).

The obtained experience and its appreciation are important not only to repeat or not a trip but also the likelihood of recommending the destination to friends and relatives, contribute to the experimented destinations to be either factors of attraction or repulsion to other potential clients (Batista, 1997). Valle et al. (2006) conducted a study in the Algarve region and concluded that there is a direct relationship between the satisfaction of tourists in a holiday destination and the intention to revisit the same destination. Byon et al. (2008) state that the destination image, quality of service and overall satisfaction are the factors that influence the most the choice of holiday destination and future behaviour, including the intention to revisit the same place.

Several authors have studied tourists' satisfaction and its behavioural consequences and this paper follows the most recent strand in the literature, where strong emphasis is given to the econometric methods employed, and, concomitantly, a quantitative approach is pursued (see Hasegawa (2009), Beerli and Martín (2005), Castro and Rui (2007), Chena and Tsai (2007), Hui and Wan (2003) and Kozak (2001), among others and references therein).

\section{Empirical Analysis}

\section{Problem Analysis}

This section examines, through an econometric model, the tourists' perspective of the Azores as a tourism destination. In particular, the econometric model examines the level of overall satisfaction of tourists with their visit of the Azores, whether tourists plan to revisit the Azores and if they would recommend a visit to the Azores to their friends or relatives.

In this analysis one aims to ascertain to what extent the characteristics of individuals who visited the Azores, such as gender, age, marital status, country of residence, level of education, occupation and if of Azorean ascendancy, impact the overall satisfaction with the visit and how their satisfaction with the visit compares with their expectations and, finally, to what extent these individual social-demographic profiles may influence the intention to revisit the Azores and to recommend the Azores as a tourist destination to friends or relatives. The tourists' satisfaction with the visit to the Azores, the fact that tourists plan to revisit the Azores, and the likelihood of recommending this destination to relatives or friends, are the questions evaluated in the questionnaire, at different levels, as illustrated in the table below. 
Given the ordinal nature of the responses, this problem naturally lends itself to the use of an ordered probit model, as described in the next section.

Table 1 Reconversion of the original level of survey questions (Questionnaire in English see Appendix I)

\begin{tabular}{|c|c|c|c|}
\hline Question & Original Level & Description & Reconversion \\
\hline \multirow{5}{*}{$\begin{array}{c}\text { Satisfaction with visit } \\
\text { to the Azores }\end{array}$} & 1 & Very unpleased & \multirow{3}{*}{0} \\
\hline & 2 & Unpleased & \\
\hline & 3 & Indifferent & \\
\hline & 4 & Pleased & 1 \\
\hline & 5 & Very pleased & 2 \\
\hline \multirow{6}{*}{$\begin{array}{l}\text { Satisfaction with visit } \\
\text { to the Azores when } \\
\text { compared with } \\
\text { expectations }\end{array}$} & 1 & Very unpleased & \multirow{4}{*}{0} \\
\hline & & & \\
\hline & 2 & Unpleased & \\
\hline & 3 & Indifferent & \\
\hline & 4 & Pleased & 1 \\
\hline & 5 & Very pleased & 2 \\
\hline \multirow{7}{*}{$\begin{array}{l}\text { Plan revisiting the } \\
\text { Azores? }\end{array}$} & 1 & $0 \%$ chances & 0 \\
\hline & 2 & Very low chance & 1 \\
\hline & 3 & Low chance & 2 \\
\hline & 4 & $50 \%$ chances & 3 \\
\hline & 5 & High chance & 4 \\
\hline & 6 & very high chance & 5 \\
\hline & 7 & $100 \%$ chances & 6 \\
\hline \multirow{5}{*}{$\begin{array}{l}\text { Recommend a visit to } \\
\text { the Azores }\end{array}$} & 1 & Would not recommend & \multirow{3}{*}{-0} \\
\hline & 2 & $\begin{array}{l}\text { Would recommend with } \\
\text { reserves }\end{array}$ & \\
\hline & 3 & Indifferent & \\
\hline & 4 & $\begin{array}{l}\text { Would recommend without } \\
\text { reserves }\end{array}$ & 1 \\
\hline & 5 & Would highly recommend & 2 \\
\hline
\end{tabular}

\section{Econometric Model}

The description of the model is made for the case where the variable is coded into three levels, although the model is extended to more levels. Individual's propensity $i$ to answer that a certain level of satisfaction attains reads:

$$
I_{i}^{*}=\beta \cdot X_{i}+\varepsilon_{i}, i=1,2, \ldots, N
$$

where:

$I_{i}^{*}$ - latent variable 
$\beta$ - vector of parameters to be estimated

$X_{i}$ - vector of independent variables (gender, education...)

$\varepsilon_{i}$ - identical and independently distributed stochastic errors which follow a $\mathrm{N}(0,1)$ distribution

However, what is observed on the data is not $I^{*}{ }_{i}$, but an indicator $I$ in which:

$$
\begin{aligned}
& I=0 \text { if } I^{*} \leq \mu_{0} \\
& I=1 \text { if } \mu_{0}<I^{*} \leq \mu_{1} \\
& I=2 \text { if } I^{*}>\mu_{1}
\end{aligned}
$$

Where $\mu_{k}(k=0,1)$ are unknown (partition) parameters of the normal distribution, estimated along with the vector $\beta$. The probabilities of an individual answering in a certain manner between three possible choices are given by:

$$
\begin{aligned}
& P\left(I=0 \mid X_{i}\right)=P\left(I^{*} \leq \mu_{0}\right)=P\left(\varepsilon_{i} \leq \mu_{0}-\beta^{t} X_{i}\right)=\Phi\left(\mu_{0}-\beta^{t} X_{i}\right) \\
& \begin{array}{l}
P\left(I=1 \mid X_{i}\right)=P\left(\mu_{0} \leq I^{*} \leq \mu_{1}\right)=P\left(\mu_{0}-\beta^{t} X_{i} \leq \varepsilon_{i} \leq \mu_{1}-\beta^{t} X_{i}\right)= \\
\quad=\Phi\left(\mu_{1}-\beta^{t} X_{i}\right)-\Phi\left(\mu_{0}-\beta^{t} X_{i}\right)
\end{array} \\
& P\left(I=2 \mid X_{i}\right)=1-P\left(I^{*} \leq \mu_{1}\right)=1-\Phi\left(\mu_{1}-\beta^{t} X_{i}\right)
\end{aligned}
$$

As usual, $\Phi$ indicates the normal cumulative distribution function.

The marginal effects of independent continuous variables, the $X_{i}^{\text {'s }}$, regarding the possibility of an individual's answer belonging to one of the three groups, is given by:

$$
\begin{aligned}
& \frac{\partial P(1=0)}{\partial X_{f}}=-\left[\Phi\left(\mu_{0}-\beta^{t} X\right)\right] \beta_{f} \\
& \frac{\partial P(1=1)}{\partial X_{f}}=\left[\Phi\left(\mu_{0}-\beta^{t} X\right)-\Phi\left(\mu_{1}-\beta^{t} X\right)\right] \beta_{f} \\
& \frac{\partial P(1=2)}{\partial X_{f}}=\left[\Phi\left(\mu_{2}-\beta^{t} X\right)\right] \beta_{f}
\end{aligned}
$$

In the case of artificial or dummy variables, the marginal effects may be determined by the following formula:

$$
\Delta=P(I=j \mid d=1)-P(I=j \mid d=0), j=0,1,2
$$


Expression (5) gives us the marginal effect on the according probability when the artificial variable changes from 0 to 1 .

The model can be estimated through maximum likelihood estimation. Given the probabilities defined in (3), the likelihood function is given by:

$$
L=\prod_{i=1}^{N} \prod_{j=0}^{2}\left\{\Phi\left(\mu_{i}-\beta^{t} X_{i}\right)-\Phi\left(\mu_{i-1}-\beta^{t} X_{i}\right)^{Z_{i j}}\right\}
$$

where $Z_{i j}$ is an indicator function type:

$$
\begin{aligned}
& Z_{i j}=1 \text { if } \mathrm{i} \in \mathrm{j} \\
& Z_{i j}=0 \text { if } \mathrm{i} \notin \mathrm{j} \quad \mathrm{i}=1, \ldots, N
\end{aligned}
$$

However, on the estimation process what is maximized is the following function:

$$
\log L=\sum_{i=1}^{N} \sum_{j=0}^{2} Z_{i j} \log \left\{\Phi\left(\mu_{i}-\beta^{t} X_{i}\right)-\Phi\left(\mu_{i-1}-\beta^{t} X_{i}\right)\right\}
$$

As long as $X_{i}$ has a constant term, as is the case here, the parameters to estimate are identified. To overcome this problem it is used, usually, a standardization which establishes that $\mu_{0}=0$. This procedure will also be used in this case. Besides, $\mu_{0-1}=-\infty \mathrm{e}$ $\mu_{2}=+\infty$.

The values of the restricted likelihood function $\log L_{R}$ and the unrestricted likelihood function $\log L_{l}$ allow us to do a likelihood ratio test:

$$
L R T=-2\left(\log L_{R}-\log L_{1}\right)
$$

This function has qui-square distribution with $m$ degrees of freedom, being $m$ the number of imposed restrictions in $\log L_{R}$.

We use LIMDEP v. 7.0 to estimate (8) and use the algorithm DavidonFletcher-Powel (DFP). The programme also estimates the variance/co-variance matrix of the estimated parameters.

\section{Data}

The data were gathered by the Studies and Consultancy Department of Norma - Açores, through a questionnaire elaborated specifically to this end. We gathered a 
total of one thousand questionnaires from tourists on the main regional airports, carried out in the summer of 2007. From these 1000 questionnaires, 110 were considered null. Thus, this study is based on a sample of 890 questionnaires. The questionnaire used in the survey can be found in Appendix 1.

This paper uses a sample of 890 questionnaires from which $50.6 \%$ were answered by male (see Table 2). The average age of the interviewees is 43 being the youngest 18 and the oldest 77 years old. The sample mode is 47 years old. Regarding the marital status of the interviewees, 633 are married, representing $71 \%$ of the sample, $23,5 \%$ are single and only $5 \%$ of the interviewees have a different marital status. The country of residence of 302 of the interviewees is Portugal, representing around $33,9 \%$; the second most important country of origin is Sweden with $10,2 \%$ and, finally, in third place, is Germany with 7,4\%. Considering Table 2, the level of education for $47,8 \%$ of the interviewees is higher education, 36,9\% has secondary school or technical. From the 890 interviewees, 127 have only attended school until the $9^{\text {th }}$ grade. From the interviewees, $80,7 \%$ have a professional activity, $9 \%$ are retired, $6,5 \%$ are students, $2,6 \%$ are housewives and $0,8 \%$ are unemployed.

Table 2 Sample descriptive statistics

\begin{tabular}{|l|c|c|c|}
\hline \multicolumn{1}{|c|}{ Variables } & Total & Men & Women \\
\hline Man & $50.56 \%$ & $100.00 \%$ & $0.00 \%$ \\
\hline Age & 43 & 43 & 43 \\
\hline Single & $23.48 \%$ & $22.89 \%$ & $24.09 \%$ \\
\hline Married & $71.12 \%$ & $72.67 \%$ & $69.55 \%$ \\
\hline Country of Residence = Portugal & $33.93 \%$ & $33.56 \%$ & $34.32 \%$ \\
\hline Country of Residence = USA & $5.17 \%$ & $4.67 \%$ & $5.68 \%$ \\
\hline Country of Residence = U. Kingdom & $4.94 \%$ & $5.56 \%$ & $4.32 \%$ \\
\hline Country of Residence = Germany & $7.42 \%$ & $8.22 \%$ & $6.59 \%$ \\
\hline Country of Residence = Denmark & $5.62 \%$ & $4.67 \%$ & $6.54 \%$ \\
\hline Country of Residence = Sweden & $10.22 \%$ & $9.78 \%$ & $10.68 \%$ \\
\hline Country of Residence = Spain & $4.27 \%$ & $4.44 \%$ & $4.09 \%$ \\
\hline Country of Residence = France & $3.71 \%$ & $4.00 \%$ & $3.41 \%$ \\
\hline Country of Residence = Holland & $3.93 \%$ & $3.11 \%$ & $4.77 \%$ \\
\hline Country of Residence = Finland & $4.61 \%$ & $4.22 \%$ & $5.00 \%$ \\
\hline Country of Residence = Canada & $2.81 \%$ & $3.33 \%$ & $2.27 \%$ \\
\hline Primary Education & $14.27 \%$ & $12.88 \%$ & $15.68 \%$ \\
\hline Employed & $80.67 \%$ & $84.44 \%$ & $76.82 \%$ \\
\hline Azorean origin & $15.84 \%$ & $13.78 \%$ & $17.95 \%$ \\
\hline Trip motive = Holidays & $83.37 \%$ & $83.33 \%$ & $83.41 \%$ \\
\hline First time in the Azores & $71.00 \%$ & $70.67 \%$ & $71.36 \%$ \\
\hline Did not consider alternative destinations & $72.81 \%$ & $72.89 \%$ & $72.73 \%$ \\
\hline Number of observations & 890 & 450 & 440 \\
\hline
\end{tabular}


Regarding Azorean origin, $84,2 \%$ of the interviewees don't have it. For the interviewed women, $18 \%$ have Azorean origin, as for men only $14 \%$ have it. The visits' main reason for $83,4 \%$ of the interviewees is holidays or pleasure, $11,2 \%$ answered that the main reason was visiting friends or relatives and $4,4 \%$ from the interviewees came on business or professional motives. $71 \%$ of the interviewees had never visited the Azores, 11,9\% had already visited and 17,1\% had already come twice or more to the Azores.

Regarding the fact of individuals having or not considered alternative destinations before coming to the Azores, 72,8\% answered that didn't considered alternative destinations. As for the probability of the interviewers revisiting the Azores, $90 \%$ answered that there's a $50 \%$ to $100 \%$ chances of them choosing the Azores destination again, and 25,6\% answered that there's 100\% chance of revisiting the Azores. As for the overall satisfaction of the interviewers regarding the visit to the Azores destination, 39,4\% answered that they were pleased and 58,3\% were very pleased. Finally, the level of satisfaction regarding the visit to the Azores destination when compared with their expectations $43,1 \%$ answered that they were pleased and $53 \%$ were very pleased.

\section{Empirical results}

Satisfaction for visiting the Azores

Concerning the satisfaction with visiting the Azores, the fact of being Dutch increases the probability of answering that he is very unpleased, unpleased or indifferent (level 0 , see Table 1 ) and decreases the probability of answering that he is very pleased (level 2); the same goes for the case of being Portuguese. The fact of being married increases the probability of answering that he is very pleased (level 2) and decreases the probability of answering that he is very unpleased, unpleased or indifferent (level 0) about his visit. The conclusion is identical for those cases in which the tourists didn't consider alternative destinations (see Table 3).

For men, the fact of being single increases the probability of answering that he is very pleased with his visit to the Azores and decreases the probability of answering that he is very unpleased, unpleased or indifferent with his visit (see Table 4). The same goes for married men.

In the case of men, the fact of his motive to visit the Azores is holidays increases the probability of answering that he is very pleased (level 2, see Table 1) with his visit to the Azores and decreases the probability of answering he is very unpleased, unpleased or indifferent with his visit (level 0). The conclusion is identical in the case of not considering alternative destinations.

For women, the fact of being French increases the probability of answering she is very pleased with her visit to the Azores and decreases the probability of answering 
she is very unpleased, unpleased or indifferent with her visit (see Table 5). The contrary goes for those who are Dutch.

Regarding the overall satisfaction of their visit to the Azores, for a level of significance at $1 \%$, as much for men as for women or for the overall of interviewees, one does not reject the null hypothesis that social-demographic profiles (gender, age, marital status, education and Azorean origin) altogether don't have explicative value. Nonetheless, for a level of significance at $5 \%$, only for the overall interviewees one rejects the null hypothesis that social-demographic profiles altogether don't have explicative value (see Table 6).

Table 3 Ordered Probit: "What is the overall satisfaction regarding your visit to the Azores" - Total

\begin{tabular}{|l|c|c|c|c|c|c|}
\hline \multicolumn{1}{|c|}{ Variables } & Coef. & $\begin{array}{c}\text { Standard } \\
\text { Error }\end{array}$ & Coef. & $\begin{array}{c}\text { Standard } \\
\text { Error }\end{array}$ & $\begin{array}{c}\text { Coef. } \\
\text { Standard } \\
\text { Error }\end{array}$ \\
\hline Intercept & 1.552 & $0.347^{*}$ & 2.071 & $0.227^{*}$ & 1.166 & $0.304^{*}$ \\
\hline Man & -0.078 & 0.084 & & & -0.050 & 0.083 \\
\hline Age & 0.001 & 0.004 & & & 0.002 & 0.004 \\
\hline Single & 0.495 & $0.201^{* *}$ & & & 0.524 & $0.199^{*}$ \\
\hline Married & 0.556 & $0.180^{*}$ & & & 0.578 & $0.178^{*}$ \\
\hline Portuguese & -0.293 & $0.141^{* *}$ & -0.303 & $0.139 * *$ & & \\
\hline American & -0.113 & 0.242 & 0.034 & 0.230 & & \\
\hline British & 0.037 & 0.224 & 0.040 & 0.222 & & \\
\hline German & 0.133 & 0.197 & 0.148 & 0.196 & & \\
\hline Danish & -0.003 & 0.211 & 0.012 & 0.210 & & \\
\hline Swedish & -0.225 & 0.172 & -0.236 & 0.171 & & \\
\hline Spanish & 0.214 & 0.240 & 0.197 & 0.238 & & \\
\hline French & 0.340 & 0.265 & 0.356 & 0.263 & & \\
\hline Dutch & -0.603 & $0.230 *$ & -0.588 & $0.228^{*}$ & & \\
\hline Finish & -0.326 & 0.220 & -0.326 & 0.219 & & \\
\hline Canadian & 0.046 & 0.303 & 0.104 & 0.293 & & \\
\hline Primary education & 0.095 & 0.127 & & & 0.053 & 0.124 \\
\hline Employed & -0.118 & 0.111 & -0.134 & 0.107 & -0.104 & 0.110 \\
\hline Azorean origin & 0.183 & 0.149 & & & 0.266 & $0.135^{* *}$ \\
\hline Trip motive=tourism & 0.154 & 0.136 & 0.165 & 0.133 & 0.199 & 0.131 \\
\hline First time in the Azores & -0.073 & 0.117 & -0.103 & 0.111 & -0.017 & 0.112 \\
\hline $\begin{array}{l}\text { Did not consider } \\
\text { alternative destinations }\end{array}$ & 0.230 & $0.095^{* *}$ & 0.236 & $0.094 * *$ & 0.255 & $0.094^{*}$ \\
\hline$\mu_{1}$ & 1.890 & $0.101^{*}$ & 1.858 & $0.099^{*}$ & 1.854 & $0.100^{*}$ \\
\hline Log-L & -656.381 & & -662.838 & & -668.534 & \\
\hline$\chi^{2}$ & 52.035 & & 39.121 & & 27.729 & \\
\hline $\mathrm{N}$ & 890 & & 890 & & 890 & \\
\hline$*$ Significant at 1\% $* *$ & Significant at $5 \%$ & $* * *$ & & & \\
\hline & & & & & \\
\hline
\end{tabular}


For both men and women, one doesn't reject the null hypothesis that the countries of residence altogether don't have explicative value. For the case of the overall of interviewees, one rejects this null hypothesis for a level of significance at $5 \%$.

Table 4 Ordered Probit: "What is the overall satisfaction regarding your visit to the Azores" - Men

\begin{tabular}{|l|c|c|c|c|c|c|}
\hline \multicolumn{1}{|c|}{ Variables } & Coef. & $\begin{array}{c}\text { Standard } \\
\text { Error }\end{array}$ & Coef. & $\begin{array}{c}\text { Standard } \\
\text { Error }\end{array}$ & $\begin{array}{c}\text { Coef. } \\
\text { Etandard } \\
\text { Error }\end{array}$ \\
\hline Intercept & 1.039 & $0.508^{* *}$ & 1.898 & $0.326^{*}$ & 0.800 & $0.457^{* * *}$ \\
\hline Age & 0.004 & 0.006 & & & 0.005 & 0.006 \\
\hline Single & 0.778 & $0.311^{* *}$ & & & 0.745 & $0.307^{* *}$ \\
\hline Married & 0.856 & $0.278^{*}$ & & & 0.808 & $0.274^{*}$ \\
\hline Portuguese & -0.293 & 0.196 & -0.265 & 0.189 & & \\
\hline American & 0.170 & 0.354 & 0.302 & 0.333 & & \\
\hline British & -0.236 & 0.290 & -0.210 & 0.288 & & \\
\hline German & 0.134 & 0.269 & 0.193 & 0.266 & & \\
\hline Danish & 0.013 & 0.314 & 0.052 & 0.312 & & \\
\hline Swedish & -0.236 & 0.243 & -0.151 & 0.240 & & \\
\hline Spanish & 0.372 & 0.335 & 0.374 & 0.331 & & \\
\hline French & 0.082 & 0.344 & 0.122 & 0.338 & & \\
\hline Dutch & -0.579 & 0.353 & -0.486 & 0.349 & & \\
\hline Finish & -0.520 & 0.317 & -0.432 & 0.313 & & \\
\hline Canadian & 0.036 & 0.394 & 0.062 & 0.371 & & \\
\hline Primary education & 0.061 & 0.186 & & & -0.016 & 0.176 \\
\hline Employed & -0.236 & 0.173 & -0.233 & 0.167 & -0.198 & 0.170 \\
\hline Azorean origin & 0.065 & 0.216 & & & 0.174 & 0.193 \\
\hline Trip motive=tourism & 0.395 & $0.186^{* *}$ & 0.403 & $0.182^{* *}$ & 0.400 & $0.177^{* *}$ \\
\hline First time in the Azores & -0.113 & 0.160 & -0.088 & 0.151 & -0.098 & 0.153 \\
\hline $\begin{array}{l}\text { Did not consider alternative } \\
\text { destinations }\end{array}$ & 0.239 & $0.135^{* * *}$ & 0.241 & $0.134^{* * *}$ & 0.228 & $0.133^{* * *}$ \\
\hline$\mu_{I}$ & 1.920 & $0.144^{*}$ & 1.869 & $0.138^{*}$ & 1.873 & $0.140^{*}$ \\
\hline Log-L & -332.173 & & -337.361 & & -339.238 & \\
\hline$\chi^{2}$ & 34.040 & & 23.665 & & 19.909 & \\
\hline $\mathrm{N}$ & 450 & & 450 & & 450 & \\
\hline$*$ Significant at & & & & \\
\hline
\end{tabular}

* Significant at 1\% ** Significant at 5\% *** Significant at 10\% 
Table 5 Ordered Probit: "What is the overall satisfaction regarding your visit to the Azores" Women

\begin{tabular}{|c|c|c|c|c|c|c|}
\hline Variables & Coef. & $\begin{array}{l}\text { Standard } \\
\text { Error }\end{array}$ & Coef. & $\begin{array}{l}\text { Standard } \\
\text { Error }\end{array}$ & Coef. & $\begin{array}{c}\text { Standard } \\
\text { Error }\end{array}$ \\
\hline Intercept & 2.030 & $0.497 *$ & 2.376 & $0.330 *$ & 1.443 & $0.414 *$ \\
\hline Age & -0.003 & 0.005 & & & -0.001 & 0.005 \\
\hline Single & 0.318 & 0.272 & & & 0.428 & 0.266 \\
\hline Married & 0.336 & 0.246 & & & 0.441 & $0.239 * * *$ \\
\hline Portuguese & -0.318 & 0.210 & -0.364 & $0.206 * * *$ & & \\
\hline American & -0.412 & 0.344 & -0.276 & 0.327 & & \\
\hline British & 0.468 & 0.370 & 0.445 & 0.367 & & \\
\hline German & 0.099 & 0.295 & 0.072 & 0.293 & & \\
\hline Danish & 0.021 & 0.290 & -0.018 & 0.289 & & \\
\hline Swedish & -0.228 & 0.251 & -0.326 & 0.246 & & \\
\hline Spanish & 0.079 & 0.350 & 0.044 & 0.348 & & \\
\hline French & 0.763 & $0.445 * * *$ & 0.731 & $0.442 * * *$ & & \\
\hline Dutch & -0.605 & $0.310 * * *$ & -0.669 & $0.308^{* *}$ & & \\
\hline Finish & -0.182 & 0.312 & -0.244 & 0.310 & & \\
\hline Canadian & 0.170 & 0.510 & 0.262 & 0.496 & & \\
\hline Primary education & 0.131 & 0.181 & & & 0.118 & 0.176 \\
\hline Employed & -0.032 & 0.150 & -0.056 & 0.144 & -0.007 & 0.146 \\
\hline Azorean origin & 0.310 & 0.213 & & & 0.337 & $0.194 * * *$ \\
\hline Trip motive=tourism & -0.100 & 0.206 & -0.111 & 0.198 & -0.048 & 0.200 \\
\hline First time in the Azores & -0.062 & 0.177 & -0.144 & 0.168 & 0.084 & 0.166 \\
\hline $\begin{array}{l}\text { Did not consider alternative } \\
\text { destinations }\end{array}$ & 0.217 & 0.138 & 0.232 & $0.136 * * *$ & 0.285 & $0.134 * *$ \\
\hline$\mu_{1}$ & 1.912 & $0.148 *$ & 1.891 & $0.146 *$ & 1.862 & $0.145^{*}$ \\
\hline Log-L & -316.204 & & -319.009 & & -325.504 & \\
\hline$\chi^{2}$ & 33.552 & & 27.942 & & 14.952 & \\
\hline $\mathrm{N}$ & 440 & & 440 & & 440 & \\
\hline
\end{tabular}

Table 6 Hypothesis Tests: Overall satisfaction with visit to the Azores

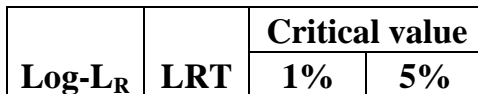

Total

\begin{tabular}{|l|l|l|l|l|}
\hline H0: Social-demographic profiles don't have explicative value & -662.84 & 12.91 & 16.81 & 12.59 \\
\hline H0: Countries of residence don't have explicative value & -668.53 & 24.31 & 24.73 & 19.68 \\
\hline
\end{tabular}

Men

\begin{tabular}{|l|l|l|l|l|}
\hline H0: Social-demographic profiles don't have explicative value & -337.36 & 10.38 & 15.09 & 11.07 \\
\hline
\end{tabular}

H0: Countries of residence don't have explicative value

\begin{tabular}{|l|l|l|l|}
-339.24 & 14.13 & 24.73 & 19.68 \\
\hline
\end{tabular}

Women

H0: Social-demographic profiles don't have explicative value

H0: Countries of residence don't have explicative value

\begin{tabular}{|l|l|l|l|}
-319.01 & 5.61 & 15.09 & 11.07 \\
\hline-325.50 & 18.6 & 24.73 & 19.68 \\
\hline
\end{tabular}

\begin{tabular}{l|l|l|l|}
-325.50 & 18.6 & 24.73 & 19.68 \\
\hline
\end{tabular}


Satisfaction with visit to the Azores when compared with expectations

In what concerns the tourist's satisfaction with visit to the Azores when compared with expectations, being a male single tourist increases the probability of answering he is very pleased (level 2, see Table 1) and decreases the probability of answering he is very unpleased, unpleased or indifferent (level 0).

Being Portuguese increases the probability of answering he is very unpleased, unpleased or indifferent and decreases the probability of answering he is very pleased, pleased with his visit to the Azores when compared with his expectations. The conclusion is similar for the fact of being Dutch and Finish (see Table 7). The fact of being single increases the probability of answering he is very pleased and decreases the probability of answering he is very unpleased, unpleased or indifferent. The conclusion is identical for the case of being married, as well as for the case of not having considered alternative destinations. Being a woman with Azorean origin increases the probability of answering that she is very pleased and decreases the probability of answering that she is very unpleased, unpleased or indifferent. The conclusion is identical for the case of being a woman and not having considered alternative destinations (see Table 9).

Regarding the overall satisfaction with the visit to the Azores when compared with their expectations, for the levels of significance at $1 \%$ and $5 \%$, one does not reject the null hypothesis that social-demographic profiles (gender, age, education and Azorean origin) altogether don't have explicative value.

Either for the overall interviewees or for men, one rejects the null hypothesis that the countries of residence altogether don't have explicative value. Regarding women one does not reject the null hypothesis for the same level of significance (see Table 10).

\section{Intention of revisiting the Azores}

Regarding tourists' plans to revisit the Azores, most variables do not present any effect statistically significant. The fact of the tourist being Swede increases the probability of answering that there is $0 \%$ chance of revisiting the Azores (level 0) and decreases the probability of answering that there is $100 \%$ chance of revisiting the Azores (level 6, see Table 1). The same is valid for the case of being Dutch. The fact of the visit's motive being holiday increases the probability of answering that there is $0 \%$ chance of revisiting the Azores and decreases the probability that there is $100 \%$ chance of revisiting the Azores. The conclusion is identical for the case of the interviewee never visited the Azores (see Table 11). For men, the fact of being Portuguese, Sweden or Dutch increases the probability of answering that there is $0 \%$ chance of revisiting the Azores and decreases the probability of answering that there is $100 \%$ chance of revisiting the Azores (see Table 12). These results are not valid for women (see table 13). The fact of the tourists having Azorean origin decreases the probability of answering that there is $0 \%$ chance of revisiting the Azores and increases 
the probability of answering that there is $100 \%$ chance of revisiting the Azores. For women and being employed decreases the probability of answering that there is $0 \%$ chance of revisiting the Azores and increases the probability of answering that there is $100 \%$ chance of revisiting the Azores. The conclusion is valid for the case of the interviewed woman having Azorean origin.

Table 7 Ordered Probit: "What's the level of satisfaction when compared with expectations?" - Total

\begin{tabular}{|l|c|c|c|c|c|c|}
\hline \multicolumn{1}{|c|}{ Variables } & Coef. & $\begin{array}{c}\text { Standard } \\
\text { Error }\end{array}$ & Coef. & $\begin{array}{c}\text { Standard } \\
\text { Error }\end{array}$ & Coef. & $\begin{array}{c}\text { Standard } \\
\text { Error }\end{array}$ \\
\hline Intercept & 1.425 & $0.337^{*}$ & 1.834 & $0.217^{*}$ & 1.084 & $0.296^{*}$ \\
\hline Man & -0.105 & 0.082 & & & -0.083 & 0.081 \\
\hline Age & 0.000 & 0.004 & & & 0.001 & 0.004 \\
\hline Single & 0.493 & $0.199^{* *}$ & & & 0.508 & $0.197^{*}$ \\
\hline Married & 0.442 & $0.177^{* *}$ & & & 0.454 & $0.176^{*}$ \\
\hline Portuguese & -0.268 & $0.137^{* *}$ & -0.273 & $0.135^{* *}$ & & \\
\hline American & -0.126 & 0.235 & -0.029 & 0.223 & & \\
\hline British & -0.006 & 0.215 & -0.010 & 0.214 & & \\
\hline German & 0.079 & 0.189 & 0.085 & 0.188 & & \\
\hline Danish & 0.213 & 0.211 & 0.219 & 0.210 & & \\
\hline Swedish & -0.100 & 0.169 & -0.110 & 0.168 & & \\
\hline Spanish & 0.283 & 0.235 & 0.269 & 0.233 & & \\
\hline French & 0.098 & 0.244 & 0.120 & 0.243 & & \\
\hline Dutch & -0.770 & $0.225^{*}$ & -0.754 & $0.224^{*}$ & & \\
\hline Finish & -0.394 & $0.214 * * *$ & -0.403 & $0.213^{* * *}$ & & \\
\hline Canadian & 0.041 & 0.290 & 0.066 & 0.280 & & \\
\hline Primary education & 0.026 & 0.122 & & & 0.011 & 0.119 \\
\hline Employed & -0.011 & 0.107 & -0.037 & 0.104 & -0.003 & 0.106 \\
\hline Azorean origin & 0.131 & 0.144 & & & 0.186 & 0.130 \\
\hline Trip motive=tourism & 0.082 & 0.132 & 0.081 & 0.129 & 0.124 & 0.128 \\
\hline First time in the Azores & -0.062 & 0.114 & -0.081 & 0.108 & -0.011 & 0.109 \\
\hline $\begin{array}{l}\text { Did not consider } \\
\text { alternative destinations }\end{array}$ & 0.165 & $0.093^{* * *}$ & 0.170 & $0.092^{* * *}$ & 0.196 & $0.091^{* *}$ \\
\hline$\mu_{I}$ & 1.761 & $0.083^{*}$ & 1.744 & $0.082^{*}$ & 1.724 & $0.082^{*}$ \\
\hline Log-L & -709.942 & & -714.848 & & -724.750 & \\
\hline$\chi^{2}$ & 46.416 & & 36.604 & & 16.799 & \\
\hline $\mathrm{N}$ & 890 & & 890 & & 890 & \\
\hline$*$ Significant at $\%$ & $-3 i g i f i c a n t$ & & \\
\hline
\end{tabular}

* Significant at 1\% ** Significant at 5\% $\quad * * *$ Significant at $10 \%$ 
Table 8 Ordered Probit: "What's the level of satisfaction when compared with expectations?" - Men

\begin{tabular}{|c|c|c|c|c|c|c|}
\hline Variables & Coef. & $\begin{array}{l}\text { Standard } \\
\text { Error }\end{array}$ & Coef. & $\begin{array}{l}\text { Standard } \\
\text { Error }\end{array}$ & Coef. & $\begin{array}{l}\text { Standard } \\
\text { Error }\end{array}$ \\
\hline Intercept & 0.725 & 0.498 & 1.635 & $0.313^{*}$ & 0.584 & 0.448 \\
\hline Age & 0.007 & 0.006 & & & 0.007 & 0.005 \\
\hline Single & 0.869 & $0.309 *$ & & & 0.800 & $0.303^{*}$ \\
\hline Married & 0.599 & $0.273 * *$ & & & 0.552 & $0.268 * *$ \\
\hline Portuguese & -0.265 & 0.191 & -0.260 & 0.184 & & \\
\hline American & 0.283 & 0.346 & 0.261 & 0.326 & & \\
\hline British & -0.325 & 0.281 & -0.314 & 0.279 & & \\
\hline German & 0.007 & 0.254 & 0.020 & 0.252 & & \\
\hline Danish & 0.436 & 0.328 & 0.434 & 0.326 & & \\
\hline Swedish & -0.126 & 0.239 & -0.087 & 0.236 & & \\
\hline Spanish & 0.605 & $0.345 * * *$ & 0.592 & $0.339 * * *$ & & \\
\hline French & -0.213 & 0.322 & -0.196 & 0.317 & & \\
\hline Dutch & -0.958 & $0.346 *$ & -0.918 & $0.343^{*}$ & & \\
\hline Finish & -0.484 & 0.310 & -0.465 & 0.306 & & \\
\hline Canadian & -0.001 & 0.379 & -0.140 & 0.355 & & \\
\hline Primary education & -0.006 & 0.181 & & & -0.047 & 0.170 \\
\hline Employed & 0.113 & 0.165 & 0.046 & 0.158 & 0.151 & 0.162 \\
\hline Azorean origin & -0.157 & 0.208 & & & -0.078 & 0.185 \\
\hline Trip motive=tourism & 0.336 & $0.182 * * *$ & 0.332 & $0.179 * * *$ & 0.298 & $0.173^{* * *}$ \\
\hline First time in the Azores & -0.207 & 0.156 & -0.152 & 0.147 & -0.180 & 0.149 \\
\hline $\begin{array}{l}\text { Did not consider alternative } \\
\text { destinations }\end{array}$ & 0.109 & 0.133 & 0.130 & 0.132 & 0.085 & 0.130 \\
\hline$\mu_{1}$ & 1.814 & $0.118^{*}$ & 1.788 & $0.116^{*}$ & 1.751 & $0.114^{*}$ \\
\hline Log-L & -355.754 & & -359.945 & & -368.368 & \\
\hline$\chi^{2}$ & 36.436 & & 28.054 & & 11.209 & \\
\hline $\mathrm{N}$ & 450 & & 450 & & 450 & \\
\hline
\end{tabular}

* Significant at $1 \% \quad$ ** Significant at 5\% *** Significant at $10 \%$ 
Table 9 Ordered Probit: "What's the level of satisfaction when compared with expectations?"

- Women

\begin{tabular}{|l|c|c|c|c|c|c|}
\hline \multicolumn{1}{|c|}{ Variables } & Coef. & $\begin{array}{c}\text { Standard } \\
\text { Error }\end{array}$ & Coef. & $\begin{array}{c}\text { Standard } \\
\text { Error }\end{array}$ & $\begin{array}{c}\text { Coef. } \\
\text { Etandard } \\
\text { Error }\end{array}$ \\
\hline Intercept & 1.840 & $0.481^{*}$ & 2.072 & $0.311^{*}$ & 1.321 & $0.399^{*}$ \\
\hline Age & -0.005 & 0.005 & & & -0.003 & 0.005 \\
\hline Single & 0.266 & 0.268 & & & 0.368 & 0.262 \\
\hline Married & 0.336 & 0.242 & & & 0.408 & 0.236 \\
\hline Portuguese & -0.254 & 0.205 & -0.291 & 0.200 & & \\
\hline American & -0.539 & 0.334 & -0.350 & 0.317 & & \\
\hline British & 0.475 & 0.354 & 0.441 & 0.351 & & \\
\hline German & 0.175 & 0.288 & 0.157 & 0.286 & & \\
\hline Danish & 0.109 & 0.284 & 0.065 & 0.282 & & \\
\hline Swedish & -0.047 & 0.247 & -0.147 & 0.242 & & \\
\hline Spanish & -0.018 & 0.335 & -0.052 & 0.331 & & \\
\hline French & 0.638 & 0.407 & 0.621 & 0.403 & & \\
\hline Dutch & -0.592 & $0.304 * * *$ & -0.648 & $0.302 * *$ & & \\
\hline Finish & -0.299 & 0.302 & -0.342 & 0.300 & & \\
\hline Canadian & 0.272 & 0.504 & 0.444 & 0.491 & & \\
\hline Primary education & 0.031 & 0.175 & & & 0.021 & 0.170 \\
\hline Employed & -0.098 & 0.146 & -0.101 & 0.141 & -0.083 & 0.143 \\
\hline Azorean origin & 0.406 & $0.208^{* * *}$ & & & 0.378 & $0.188^{* *}$ \\
\hline Trip motive=tourism & -0.177 & 0.201 & -0.186 & 0.193 & -0.098 & 0.194 \\
\hline First time in the Azores & 0.061 & 0.172 & -0.037 & 0.163 & 0.186 & 0.161 \\
\hline $\begin{array}{l}\text { Did not consider alternative } \\
\text { destinations }\end{array}$ & 0.232 & $0.135 * * *$ & 0.249 & $0.133^{* * *}$ & 0.307 & $0.131^{* *}$ \\
\hline$\mu_{I}$ & 1.767 & $0.122^{*}$ & 1.745 & $0.120^{*}$ & 1.723 & $0.119 *$ \\
\hline Log-L & -340.456 & & -344.320 & & -350.149 & \\
\hline$\chi^{2}$ & 36.383 & & 28.655 & & 16.997 & \\
\hline N & 440 & & 440 & & 440 & \\
\hline$*$ Significan at & & & & \\
\hline
\end{tabular}

* Significant at $1 \% \quad * *$ Significant at $5 \% \quad * * *$ Significant at $10 \%$

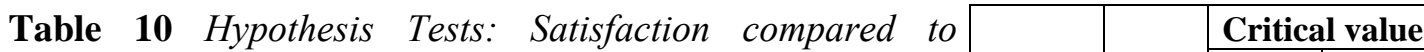
expectations

\begin{tabular}{|l|l|l|l|l|}
\hline Total & \multicolumn{4}{|l|}{$\mid$} \\
\hline H0: Social-demographic profiles don't have explicative value & -714.85 & 9.81 & 16.81 & 12.59 \\
\hline H0: Countries of residence don't have explicative value & -724.75 & 29.62 & 24.73 & 19.68 \\
\hline Men & -359.95 & 8.38 & 15.09 & 11.07 \\
\hline H0: Social-demographic profiles don't have explicative value & -368.37 & 25.23 & 24.73 & 19.68 \\
\hline H0: Countries of residence don't have explicative value & \multicolumn{5}{|l|}{} \\
\hline Women & -344.32 & 7.73 & 15.09 & 11.07 \\
\hline H0: Social-demographic profiles don't have explicative value & -350.15 & 19.39 & 24.73 & 19.68 \\
\hline H0: Countries of residence don't have explicative value
\end{tabular}


Table 11 Ordered Probit: "Do you have plans for revisiting the Azores?" - Total

\begin{tabular}{|c|c|c|c|c|c|c|}
\hline Variables & Coef. & $\begin{array}{l}\text { Standard } \\
\text { Error }\end{array}$ & Coef. & $\begin{array}{l}\text { Standard } \\
\text { Error }\end{array}$ & Coef. & $\begin{array}{c}\text { Standard } \\
\text { Error }\end{array}$ \\
\hline Intercept & 2.998 & $0.300 *$ & 3.318 & 0.189* & 2.844 & $0.265 *$ \\
\hline Man & 0.042 & 0.072 & & & 0.058 & 0.072 \\
\hline Age & 0.002 & 0.003 & & & 0.002 & 0.003 \\
\hline Single & 0.100 & 0.182 & & & 0.101 & 0.181 \\
\hline Married & -0.004 & 0.164 & & & -0.004 & 0.163 \\
\hline Portuguese & -0.108 & 0.120 & -0.104 & 0.118 & & \\
\hline American & -0.143 & 0.217 & 0.075 & 0.206 & & \\
\hline British & 0.167 & 0.187 & 0.203 & 0.186 & & \\
\hline German & -0.058 & 0.162 & -0.063 & 0.161 & & \\
\hline Danish & -0.106 & 0.176 & -0.108 & 0.175 & & \\
\hline Swedish & -0.328 & $0.146 * *$ & -0.339 & $0.146 * *$ & & \\
\hline Spanish & 0.007 & 0.196 & -0.017 & 0.195 & & \\
\hline French & 0.085 & 0.210 & 0.138 & 0.209 & & \\
\hline Dutch & -0.448 & $0.201 * *$ & -0.462 & $0.200 * *$ & & \\
\hline Finish & 0.041 & 0.190 & 0.009 & 0.189 & & \\
\hline Canadian & 0.068 & 0.268 & 0.250 & 0.259 & & \\
\hline Primary education & 0.138 & 0.111 & & & 0.141 & 0.108 \\
\hline Employed & 0.091 & 0.096 & 0.047 & 0.092 & 0.105 & 0.095 \\
\hline Azorean origin & 0.435 & $0.131 *$ & & & 0.460 & $0.121 *$ \\
\hline Trip motive=tourism & -0.431 & $0.123 *$ & -0.489 & $0.120 *$ & -0.424 & $0.119 *$ \\
\hline First time in the Azores & -0.618 & $0.103 *$ & -0.712 & $0.098 *$ & -0.607 & $0.099 *$ \\
\hline $\begin{array}{l}\text { Did not consider } \\
\text { alternative destinations }\end{array}$ & 0.061 & 0.082 & 0.086 & 0.081 & 0.084 & 0.081 \\
\hline$\mu_{1}$ & 0.535 & $0.066^{*}$ & 0.536 & $0.066^{*}$ & 0.534 & $0.066 *$ \\
\hline$\mu_{2}$ & 1.014 & $0.056 *$ & 1.016 & $0.056 *$ & 1.011 & $0.056 *$ \\
\hline$\mu_{3}$ & 1.979 & $0.046^{*}$ & 1.978 & $0.046^{*}$ & 1.966 & $0.046 *$ \\
\hline$\mu_{4}$ & 2.548 & $0.045^{*}$ & 2.541 & $0.044 *$ & 2.527 & $0.044 *$ \\
\hline$\mu_{5}$ & 3.172 & $0.053 *$ & 3.158 & $0.052 *$ & 3.145 & $0.053 *$ \\
\hline Log-L & -674.852 & & -1388.859 & & -1388.752 & \\
\hline$\gamma^{2}$ & 125.565 & & 171.591 & & 171.806 & \\
\hline $\mathrm{N}$ & 450 & & 890 & & 890 & \\
\hline
\end{tabular}

* Significant at $1 \% \quad * *$ Significant at $5 \% \quad$ *** Significant at $10 \%$ 
Table 12 Ordered Probit: "Do you have plans for revisiting the Azores?" - Men

\begin{tabular}{|c|c|c|c|c|c|c|}
\hline Variables & Coef. & $\begin{array}{l}\text { Standard } \\
\text { Error }\end{array}$ & Coef. & $\begin{array}{l}\text { Standard } \\
\text { Error }\end{array}$ & Coef. & $\begin{array}{c}\text { Standard } \\
\text { Error }\end{array}$ \\
\hline Intercept & 3.576 & $0.453^{*}$ & 3.859 & $0.277^{*}$ & 3.306 & $0.410 *$ \\
\hline Age & -0.003 & 0.005 & & & -0.003 & 0.005 \\
\hline Single & 0.447 & 0.282 & & & 0.384 & 0.281 \\
\hline Married & 0.335 & 0.253 & & & 0.235 & 0.251 \\
\hline Portuguese & -0.293 & $0.169 * * *$ & -0.216 & 0.163 & & \\
\hline American & 0.223 & 0.331 & 0.572 & $0.312 * * *$ & & \\
\hline British & -0.025 & 0.251 & 0.018 & 0.250 & & \\
\hline German & -0.342 & 0.219 & -0.311 & 0.218 & & \\
\hline Danish & -0.356 & 0.263 & -0.355 & 0.262 & & \\
\hline Swedish & -0.648 & $0.207 *$ & -0.597 & $0.205^{*}$ & & \\
\hline Spanish & -0.372 & 0.269 & -0.383 & 0.269 & & \\
\hline French & 0.112 & 0.292 & 0.240 & 0.287 & & \\
\hline Dutch & -1.002 & 0.309* & -0.964 & $0.307 *$ & & \\
\hline Finish & -0.245 & 0.273 & -0.257 & 0.271 & & \\
\hline Canadian & -0.074 & 0.362 & 0.249 & 0.343 & & \\
\hline Primary education & 0.192 & 0.164 & & & 0.172 & 0.155 \\
\hline Employed & -0.163 & 0.150 & -0.163 & 0.144 & -0.156 & 0.148 \\
\hline Azorean origin & 0.571 & 0.198* & & & 0.705 & $0.180 *$ \\
\hline Trip motive=tourism & -0.343 & $0.170 * *$ & -0.418 & $0.167 * *$ & -0.374 & $0.163 * *$ \\
\hline First time in the Azores & -0.649 & $0.140 *$ & -0.711 & $0.133^{*}$ & -0.648 & 0.135* \\
\hline $\begin{array}{l}\text { Did not } \\
\text { alternative destinations }\end{array}$ & -0.133 & 0.117 & -0.120 & 0.117 & -0.113 & 0.115 \\
\hline$\mu_{1}$ & 0.556 & $0.103 *$ & 0.544 & $0.102 *$ & 0.550 & $0.101^{*}$ \\
\hline$\mu_{2}$ & 1.111 & $0.084 *$ & 1.093 & $0.083 *$ & 1.090 & $0.082 *$ \\
\hline$\mu_{3}$ & 2.147 & 0.066* & 2.117 & 0.066* & 2.092 & $0.065 * *$ \\
\hline$\mu_{4}$ & 2.726 & $0.064 *$ & 2.686 & $0.063 *$ & 2.650 & $0.063 *$ \\
\hline$\mu_{5}$ & 3.386 & 0.076* & 3.332 & $0.075 *$ & 3.288 & $0.075^{*}$ \\
\hline Log-L & -674.852 & & -682.317 & & -686.373 & \\
\hline$\chi^{2}$ & 125.565 & & 110.634 & & 102.521 & \\
\hline $\mathrm{N}$ & 450 & & 450 & & 450 & \\
\hline
\end{tabular}


Table 13 Ordered Probit: "Do you have plans for revisiting the Azores?" - Women

\begin{tabular}{|c|c|c|c|c|c|c|}
\hline Variables & Coef. & $\begin{array}{l}\text { Standard } \\
\text { Error }\end{array}$ & Coef. & $\begin{array}{l}\text { Standard } \\
\text { Error }\end{array}$ & Coef. & $\begin{array}{l}\text { Standard } \\
\text { Error }\end{array}$ \\
\hline Intercept & 2.652 & $0.417^{*}$ & 3.020 & $0.265 *$ & 2.592 & $0.350 *$ \\
\hline Age & 0.006 & 0.004 & & & 0.005 & 0.004 \\
\hline Single & -0.076 & 0.242 & & & -0.077 & 0.239 \\
\hline Married & -0.099 & 0.221 & & & -0.099 & 0.216 \\
\hline Portuguese & 0.040 & 0.177 & -0.003 & 0.174 & & \\
\hline American & -0.463 & 0.299 & -0.307 & 0.286 & & \\
\hline British & 0.330 & 0.284 & 0.357 & 0.283 & & \\
\hline German & 0.270 & 0.244 & 0.253 & 0.242 & & \\
\hline Danish & 0.107 & 0.240 & 0.118 & 0.239 & & \\
\hline Swedish & -0.065 & 0.213 & -0.088 & 0.209 & & \\
\hline Spanish & 0.384 & 0.291 & 0.342 & 0.289 & & \\
\hline French & 0.018 & 0.309 & -0.007 & 0.308 & & \\
\hline Dutch & -0.011 & 0.269 & -0.034 & 0.268 & & \\
\hline Finish & 0.343 & 0.269 & 0.324 & 0.266 & & \\
\hline Canadian & 0.122 & 0.408 & 0.184 & 0.396 & & \\
\hline Primary education & 0.121 & 0.155 & & & 0.130 & 0.152 \\
\hline Employed & 0.252 & $0.127 * *$ & 0.208 & $0.123 * * *$ & 0.259 & $0.126 * *$ \\
\hline Azorean origin & 0.330 & $0.180 * * *$ & & & 0.238 & 0.167 \\
\hline Trip motive=tourism & -0.606 & $0.183^{*}$ & -0.654 & $0.178 *$ & -0.528 & $0.178 *$ \\
\hline First time in the Azores & -0.600 & $0.155^{*}$ & -0.702 & $0.147 *$ & -0.553 & $0.146 *$ \\
\hline $\begin{array}{l}\text { Did not } \\
\text { alternative destinations }\end{array}$ & 0.273 & $0.118 * *$ & 0.310 & $0.117 *$ & 0.287 & $0.116^{* *}$ \\
\hline$\mu_{1}$ & 0.558 & $0.091 *$ & 0.559 & $0.091^{*}$ & 0.545 & $0.089 *$ \\
\hline$\mu_{2}$ & 1.011 & 0.079* & 1.013 & $0.079 *$ & 0.986 & $0.078 *$ \\
\hline$\mu_{3}$ & 1.962 & 0.066* & 1.961 & $0.065 *$ & 1.919 & 0.065* \\
\hline$\mu_{4}$ & 2.549 & 0.064* & 2.543 & $0.063 *$ & 2.498 & 0.063* \\
\hline$\mu_{5}$ & 3.163 & $0.075 *$ & 3.149 & $0.075^{*}$ & 3.108 & $0.075^{*}$ \\
\hline Log-L & -686.792 & & -690.287 & & -692.065 & \\
\hline$\chi^{2}$ & 99.030 & & 92.041 & & 88.485 & \\
\hline $\mathrm{N}$ & 440 & & 440 & & 440 & \\
\hline
\end{tabular}


Table 14 Hypothesis Tests: Plans for revisiting the Azores

\begin{tabular}{|c|c|c|c|c|}
\hline & \multirow[b]{2}{*}{$\mathbf{L o g}-\mathbf{L}_{\mathbf{R}}$} & \multirow[b]{2}{*}{ LRT } & \multicolumn{2}{|c|}{ Critical value } \\
\hline & & & $1 \%$ & $5 \%$ \\
\hline \multicolumn{5}{|l|}{ Total } \\
\hline H0: Social-demographic profiles don’t have explicative value & -1388.86 & 14.94 & 16.81 & 12.59 \\
\hline H0: Countries of residence don’t have explicative value & -1388.75 & 14.72 & 24.73 & 19.68 \\
\hline \multicolumn{5}{|l|}{ Men } \\
\hline H0: Social-demographic profiles don’t have explicative value & -682.32 & 14.93 & 15.09 & 11.07 \\
\hline H0: Countries of residence don’t have explicative value & -686.37 & 23.04 & 24.73 & 19.68 \\
\hline \multicolumn{5}{|l|}{ Women } \\
\hline H0: Social-demographic profiles don’t have explicative value & -690.29 & 6.99 & 15.09 & 11.07 \\
\hline H0: Countries of residence don’t have explicative value & -692.07 & 10.55 & 24.73 & 19.68 \\
\hline
\end{tabular}

Regarding the possibility of revisiting the Azores, one rejects the null hypothesis that social-demographic profiles (gender, age, marital status, education, and Azorean origin) altogether don't have explicative value. Concerning women one does not reject the null hypothesis at a level of $5 \%$ significance. For a level of significance at $1 \%$, one does not reject the null hypothesis that social-demographic profiles altogether don't have explicative value and that the countries of origin altogether also don't have explicative value.

\section{Likelihood of a tourist recommending a visit to the Azores}

Regarding the analysis of the likelihood of a tourist recommending a visit to the Azores to relatives or friends, the fact of being Portuguese, German, Sweden, Dutch or Canadian increases the probability of answering that they would not recommend the Azores, would recommend with reserves or are indifferent (level 0, see Table 1) and decreases the probability of answering that they would indeed recommend a visit to the Azores (level 2).

The fact of the tourist having Azorean origin increases the likelihood of not recommending the Azores' destination, recommending with some reserves or being indifferent and decreases the likelihood of recommending a visit to the Azores (see Table 15).

The fact of the tourist not having considered alternative destinations decreases the likelihood of not recommending the Azores, recommending with some reserves or being indifferent and increases the likelihood of recommending the visit to the Azores. The conclusion is valid in case the interviewee having a level of education $<=9^{\circ}$ grade.

Regarding men, the fact of being married or older, decreases the likelihood of not recommending the Azores, recommending with some reserves or being indifferent and increases the likelihood of recommending the visit to the Azores. Conclusions are identical if the motive of visiting the Azores is holidays or if the interviewee is older (see Table 16). 
The fact of the tourist being male and not having considered alternative destinations decreases the likelihood of not recommending the Azores, recommending with some reserves or being indifferent and increases the likelihood of recommending the visit to the Azores. The conclusion is valid for the case of the interviewee being a woman.

For women who do not consider alternative destinations the level of likelihood of recommending the Azores is superior (level 2, see Table 1) and inferior the likelihood of not recommending the Azores, recommending with some reserves or being indifferent (level 0).

Table 15 Ordered Probit: "Likelihood of recommending a visit to the Azores" - Total

\begin{tabular}{|l|c|c|c|c|c|c|}
\hline \multicolumn{1}{|c|}{ Variables } & Coef. & $\begin{array}{c}\text { Standard } \\
\text { Error }\end{array}$ & Coef. & $\begin{array}{c}\text { Standard } \\
\text { Error }\end{array}$ & $\begin{array}{c}\text { Coef. } \\
\text { Error }\end{array}$ \\
\hline Intercept & 1.628 & $0.351^{*}$ & 2.125 & $0.228^{*}$ & 0.879 & $0.305^{*}$ \\
\hline Man & 0.034 & 0.084 & & & 0.040 & 0.083 \\
\hline Age & 0.007 & $0.004^{* * *}$ & & & 0.009 & $0.004^{* *}$ \\
\hline Single & 0.146 & 0.207 & & & 0.195 & 0.205 \\
\hline Married & 0.179 & 0.185 & & & 0.231 & 0.184 \\
\hline Portuguese & -0.632 & $0.150^{*}$ & -0.645 & $0.148^{*}$ & & \\
\hline American & -0.274 & 0.253 & -0.232 & 0.242 & & \\
\hline British & -0.269 & 0.231 & -0.225 & 0.230 & & \\
\hline German & -0.362 & $0.200^{* * *}$ & -0.352 & $0.199^{* * *}$ & & \\
\hline Danish & -0.182 & 0.224 & -0.153 & 0.223 & & \\
\hline Swedish & -0.492 & $0.180^{*}$ & -0.480 & $0.179 *$ & & \\
\hline Spanish & -0.322 & 0.239 & -0.324 & 0.238 & & \\
\hline French & -0.402 & 0.251 & -0.419 & $0.249 * * *$ & & \\
\hline Dutch & -0.650 & $0.235^{*}$ & -0.639 & $0.234^{*}$ & & \\
\hline Finish & -0.342 & 0.233 & -0.346 & 0.231 & & \\
\hline Canadian & -0.832 & $0.287 *$ & -0.847 & $0.278^{*}$ & & \\
\hline Primary education & 0.220 & $0.131^{* * *}$ & & & 0.160 & 0.127 \\
\hline Employed & 0.004 & 0.111 & -0.025 & 0.107 & 0.026 & 0.110 \\
\hline Azorean origin & -0.018 & 0.146 & & & 0.019 & 0.133 \\
\hline Trip motive=tourism & 0.048 & 0.135 & 0.064 & 0.133 & 0.096 & 0.131 \\
\hline First time in the Azores & -0.125 & 0.118 & -0.132 & 0.111 & -0.013 & 0.112 \\
\hline $\begin{array}{l}\text { Did not consider alternative } \\
\text { destinations }\end{array}$ & 0.288 & $0.095^{*}$ & 0.297 & $0.094^{*}$ & 0.281 & $0.094^{*}$ \\
\hline$\mu_{1}$ & 1.529 & $0.084^{*}$ & 1.513 & $0.083^{*}$ & 1.499 & $0.082^{*}$ \\
\hline Log-L & -665.746 & & -670.847 & & -678.711 & \\
\hline$\chi^{2}$ & 49.775 & & 39.573 & & 23.845 & \\
\hline N & 890 & & 890 & & 890 & \\
\hline$*$ Significant at 1\% & & & & \\
\hline
\end{tabular}


Table 16 Ordered Probit: "Likelihood of recommending a visit to the Azores"-Men

\begin{tabular}{|l|c|c|c|c|c|c|}
\hline \multicolumn{1}{|c|}{ Variables } & Coef. & $\begin{array}{c}\text { Standard } \\
\text { Error }\end{array}$ & Coef. & $\begin{array}{c}\text { Standard } \\
\text { Error }\end{array}$ & $\begin{array}{c}\text { Coef. } \\
\text { Standard } \\
\text { Error }\end{array}$ \\
\hline Intercept & 1.039 & $0.518^{* *}$ & 1.909 & $0.329^{*}$ & 0.714 & 0.463 \\
\hline Age & 0.012 & $0.006^{* *}$ & & & 0.013 & $0.006^{* *}$ \\
\hline Single & 0.420 & 0.317 & & & 0.388 & 0.315 \\
\hline Married & 0.508 & $0.285^{* * *}$ & & & 0.453 & 0.282 \\
\hline Portuguese & -0.439 & $0.207 * *$ & -0.445 & $0.199^{* *}$ & & \\
\hline American & 0.144 & 0.377 & 0.159 & 0.355 & & \\
\hline British & -0.411 & 0.299 & -0.342 & 0.298 & & \\
\hline German & -0.342 & 0.271 & -0.283 & 0.268 & & \\
\hline Danish & -0.174 & 0.329 & -0.122 & 0.324 & & \\
\hline Swedish & -0.367 & 0.255 & -0.283 & 0.251 & & \\
\hline Spanish & 0.170 & 0.352 & 0.211 & 0.352 & & \\
\hline French & -0.179 & 0.355 & -0.181 & 0.344 & & \\
\hline Dutch & -1.136 & $0.349 *$ & -1.026 & $0.344^{*}$ & & \\
\hline Finish & -0.447 & 0.333 & -0.364 & 0.327 & & \\
\hline Canadian & -0.481 & 0.386 & -0.526 & 0.366 & & \\
\hline Primary education & 0.085 & 0.192 & & & 0.021 & 0.181 \\
\hline Employed & -0.043 & 0.175 & -0.076 & 0.169 & -0.026 & 0.172 \\
\hline Azorean origin & -0.115 & 0.218 & & & -0.053 & 0.194 \\
\hline Trip motive=tourism & 0.384 & $0.189^{* *}$ & 0.436 & $0.186^{* *}$ & 0.347 & $0.180^{* * *}$ \\
\hline First time in the Azores & -0.320 & $0.165^{* * *}$ & -0.290 & $0.156^{* * *}$ & -0.283 & $0.158^{* * *}$ \\
\hline $\begin{array}{l}\text { Did not consider alternative } \\
\text { destinations }\end{array}$ & 0.303 & $0.138^{* *}$ & 0.314 & $0.136 * *$ & 0.272 & $0.134^{* *}$ \\
\hline$\mu_{1}$ & 1.623 & $0.127 *$ & 1.581 & $0.123^{*}$ & 1.579 & $0.125^{*}$ \\
\hline Log-L & -322.777 & & -328.353 & & -332.074 & \\
\hline$\chi^{2}$ & 39.156 & & 28.005 & & 20.563 & \\
\hline $\mathrm{N}$ & 450 & & 450 & & 450 & \\
\hline$*$ Significan & & & & \\
\hline
\end{tabular}

* Significant at $1 \% \quad$ ** Significant at $5 \% \quad$ *** Significant at $10 \%$ 
Table 17 Ordered Probit: "Likelihood of recommending a visit to the Azores" Women

\begin{tabular}{|l|c|c|c|c|c|c|}
\hline \multicolumn{1}{|c|}{ Variables } & Coef. & $\begin{array}{c}\text { Standard } \\
\text { Error }\end{array}$ & Coef. & $\begin{array}{c}\text { Standard } \\
\text { Error }\end{array}$ & Coef. & $\begin{array}{c}\text { Standard } \\
\text { Error }\end{array}$ \\
\hline Intercept & 2.149 & $0.501^{*}$ & 2.378 & $0.331^{*}$ & 0.987 & $0.410^{* *}$ \\
\hline Age & 0.003 & 0.005 & & & 0.006 & 0.005 \\
\hline Single & -0.007 & 0.280 & & & 0.136 & 0.274 \\
\hline Married & -0.036 & 0.253 & & & 0.126 & 0.247 \\
\hline Portuguese & -0.843 & $0.229^{*}$ & -0.866 & $0.227^{*}$ & & \\
\hline American & -0.673 & $0.360^{* * *}$ & -0.632 & $0.346^{* * *}$ & & \\
\hline British & -0.088 & 0.381 & -0.085 & 0.378 & & \\
\hline German & -0.460 & 0.302 & -0.488 & 0.301 & & \\
\hline Danish & -0.218 & 0.316 & -0.223 & 0.315 & & \\
\hline Swedish & -0.661 & $0.267^{* *}$ & -0.700 & $0.263^{*}$ & & \\
\hline Spanish & -0.809 & $0.343^{* *}$ & -0.819 & $0.342^{* *}$ & & \\
\hline French & -0.670 & $0.369^{* * *}$ & -0.723 & $0.367^{* *}$ & & \\
\hline Dutch & -0.346 & 0.337 & -0.377 & 0.336 & & \\
\hline Finish & -0.321 & 0.334 & -0.368 & 0.331 & & \\
\hline Canadian & -1.313 & $0.443^{*}$ & -1.351 & $0.431^{*}$ & & \\
\hline Primary education & 0.297 & 0.188 & & & 0.311 & $0.182^{* * *}$ \\
\hline Employed & 0.071 & 0.148 & 0.020 & 0.143 & 0.102 & 0.145 \\
\hline Azorean origin & 0.072 & 0.206 & & & 0.066 & 0.188 \\
\hline Trip motive=tourism & -0.289 & 0.203 & -0.319 & 0.197 & -0.210 & 0.197 \\
\hline First time in the Azores & 0.071 & 0.175 & 0.036 & 0.165 & 0.289 & $0.163^{* * *}$ \\
\hline $\begin{array}{l}\text { Did not consider alternative } \\
\text { destinations }\end{array}$ & 0.368 & $0.138^{*}$ & 0.380 & $0.137^{*}$ & 0.321 & $0.134^{* *}$ \\
\hline$\mu_{1}$ & 1.512 & $0.116^{*}$ & 1.505 & $0.115^{*}$ & 1.458 & $0.112^{*}$ \\
\hline Log-L & -329.244 & & -331.018 & & -340.491 & \\
\hline$\chi^{2}$ & 37.410 & & 33.861 & & 14.916 & \\
\hline $\mathrm{N}$ & 440 & & 440 & & 440 & \\
\hline$*$ Sigificat & -29 & & & & \\
\hline
\end{tabular}

\footnotetext{
* Significant at $1 \% \quad * *$ Significant at $5 \% \quad * * *$ Significant at $10 \%$
} 
Table 18 Hypothesis Tests: Likelihood of recommending a visit to the Azores

\begin{tabular}{|c|c|c|c|c|}
\hline & \multirow[b]{2}{*}{$\log -\mathbf{L}_{\mathbf{R}}$} & \multirow[b]{2}{*}{ LRT } & \multicolumn{2}{|c|}{ Critical value } \\
\hline & & & $1 \%$ & $5 \%$ \\
\hline \multicolumn{5}{|l|}{ Total } \\
\hline H0: Social-demographic profiles don't have explicative value & -670.85 & 10.20 & 16.81 & 12.59 \\
\hline H0: Countries of residence don’t have explicative value & -678.71 & 25.93 & 24.73 & 19.68 \\
\hline \multicolumn{5}{|l|}{ Men } \\
\hline H0: Social-demographic profiles don't have explicative value & -328.35 & 11.15 & 15.09 & 11.07 \\
\hline H0: Countries of residence don’t have explicative value & -332.07 & 18.59 & 24.73 & 19.68 \\
\hline \multicolumn{5}{|l|}{ Women } \\
\hline H0: Social-demographic profiles don't have explicative value & -331.02 & 3.55 & 15.09 & 11.07 \\
\hline H0: Countries of residence don't have explicative value & -340.49 & 22.49 & 24.73 & 19.68 \\
\hline
\end{tabular}

Regarding the likelihood of recommending a visit to the Azores for a level of significance at $5 \%$, one rejects the null hypothesis that the countries of origin altogether don't have explicative value. Regarding men one does not reject the null hypothesis for the same level of significance. However, with significance at $1 \%$ one does not reject this hypothesis either for men or women.

With significance at $1 \%$ level one does not reject the null hypothesis that the social-demographic profiles altogether don't have explicative value. But significance at $5 \%$ level one rejects this null hypothesis for the case of men (see Table 18).

\section{Conclusions and recommendations}

This paper uses a new micro-survey on a representative sample of tourists who visited the Azores, an emerging Portuguese Archipelago tourist destination, to quantify the determinants of tourist satisfaction, the intention to revisit the destination and the likelihood of recommending the destination to friends and relatives. Regarding the level of tourists' satisfaction with their visit to the Azores, one verifies that Portuguese and Dutch tourists are very unpleased with their visit. The results indicate that female tourists and with French nationality are very pleased with their visit, although it's worth noticing that the level of significance is $10 \%$. Regarding the tourist' intention of revisiting the Azores, the fact of the tourist being Sweden or Dutch decreases the probability of revisiting the Azores.

On the other hand, the fact of the tourist having Azorean origin increases the probability of revisiting the Autonomous Region of the Azores. Regarding the likelihood of recommending the destination to friends and relatives, one verifies that Sweden, Dutch, Portuguese and Canadian tourists don't show likelihood of recommending this destination. Regarding women who don't consider alternative holiday destinations, one concludes that they show intention of recommending the Azores destination to relatives and friends. 
If one analyses tourists who don't considered alternative destinations, one verifies that they are pleased with their visit. However, the results show that, regarding tourist' satisfaction when compared with their expectations, Dutch tourists are very unpleased and that male tourist are very pleased with their visit to the Azores. Tourism economic agents and policymakers should be attentive to the expectations surrounding a tourist destination and how to best allocated resources that lead to the fulfilment of the expectations and not dissatisfaction.

\section{References}

1. Andreassen, T., B. Lindestad (1998) Customer loyalty and complex services: The impact of corporate image on quality, customer satisfaction and loyalty for customers with varying degrees of service expertise. The International Journal of Service Industry Management, 9(1), pp. 7-23

2. Batista, M. (1997) Turismo Competitividade Sustentável. Editorial Verbom.

3. Beerli, A., Martín, J. (2005) Tourists' characteristics and the perceived image of tourist destination: a quantitative analysis - a case study of Lanzarote Spain. Tourism Management, 25(5), pp. 626-636.

4. Byon, K., J. Zhang, Y. Ko (2008) Dimensions of destination image: Development of a scale. Paper presented at the 2008 North American Society for Sport Management Conference (NASSM 2008), Toronto, Ontario, $28^{\text {th }}-31^{\text {st }}$ May 2008

5. Castro, C., Armario, E., Rui, D. (2007) The influence of market heterogeneity on the relationship between a destination's image and tourists' future behavior. Tourism Management, 28(1), pp. 175-187.

6. Chen, C., D. Tsai, (2007) How destination image and evaluative factors affect behavioral intentions. Tourism Management, 28(4), pp. 1115-1122.

7. Fernández, M., A. Picos (2005) Predicciones en el nivel de satisfacción percibida por los turistas a partir de variables motivacionales y devaloración de la visita. Tribuna de Economía, Marzo-Abril 2005. N. ${ }^{\circ}$ 821ICE 241.

8. Flecha, A., W. Damiani (2006) Turismo: Responsabilidade Social e Ambiental. Paper presented at the IV Seminário de Pesquisa em Turismo do Mercosul, Rio de Janeiro, Brazil.

9. Gunn, C. (1993) Tourism planning - basics concepts and cases. New York: Taylor \& Francis, $3^{\text {rd }}$ ed.

10. Hasegawa, H. (2009) Analyzing tourists' satisfaction: A multivariate ordered probit approach. Tourism Management, in press. Available online 20 February 2009.

11. Hui, T, Want, T. (2003) Singapore's image as a tourist destination. International Journal of Tourism Research, 5(4), pp. 305-313. 
12. Kozak, M. (2001) Repeaters' behavior at two distinct destination. Annals of Tourism Research, 28(3), pp. 785-808.

13. Marino, E. (2007) The strategic dimension of destination image. An analysis of the French Riviera image from the Italian tourists' perceptions. Discussion Paper, University of Naples "Federico II" - Faculty of Economics.

14. Menezes, A., A. Moniz, Vieira, J. (2008) Determinants of length of stay: A parametric survival analysis. Tourism Economics, 14(1), pp. 205-222.

15. Serviço Regional de Estatística dos Açores, http://estatistica.azores.gov.pt/, Accessed on 29.09.2008.

16. Valle, P., J. Silva, J. Medes, M. Guerreiro (2006) Tourist satisfaction and destination loyalty intention: A structural and categorical analysis. International Journal of Business Science and Applied Management, 1(1), 25-44

RECEIVED: 14.11 .2008

ACCEPTED: 20.04.2009 


\section{Appendix I}

\begin{tabular}{|c|c|c|c|}
\hline 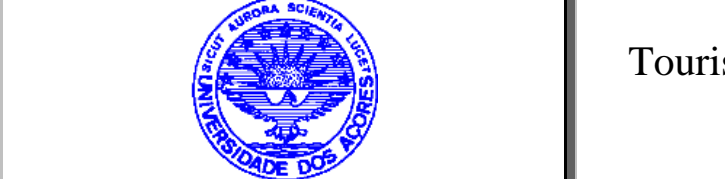 & \multicolumn{2}{|c|}{ Tourist Departure Questionnaire } & Assinatura \\
\hline \multicolumn{4}{|c|}{$\begin{array}{l}\text { Good Day / good afternoon / good night, my name is............ I am interviewer of the Department of Studies and Consultadoria of } \\
\text { the Norma-Açores and we are to accomplish a study for UA in order to know the opinion about the quality of the tourist } \\
\text { experience in Azores. We thanked all the collaboration that can render us at once and we informed that the data that it will supply } \\
\text { us will have statistical treatment and they will stay confidential. } \\
\text { YOU ARE RESIDENT IN AZORES } \\
\text { YOU SLEPT AT LEAST ONE NIGHT IN AÇORES } \\
\text { Y YES (FINISH) } \\
\square \text { NO (CONTINUE) }\end{array}$} \\
\hline 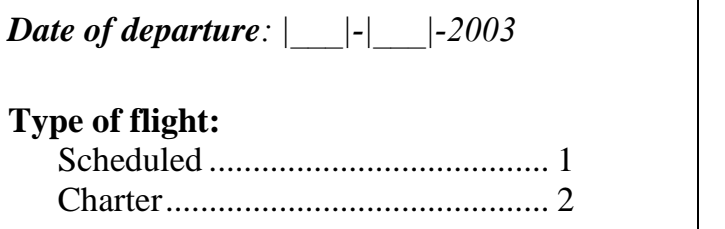 & \multicolumn{3}{|c|}{ 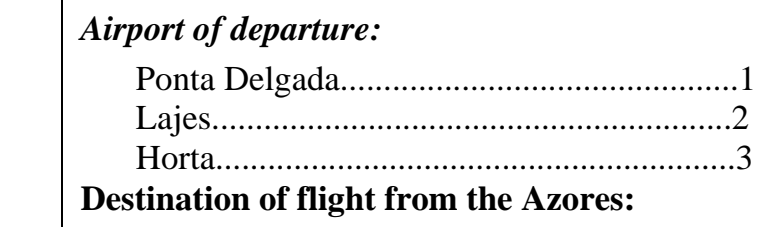 } \\
\hline
\end{tabular}

\section{Part - The individual identification}

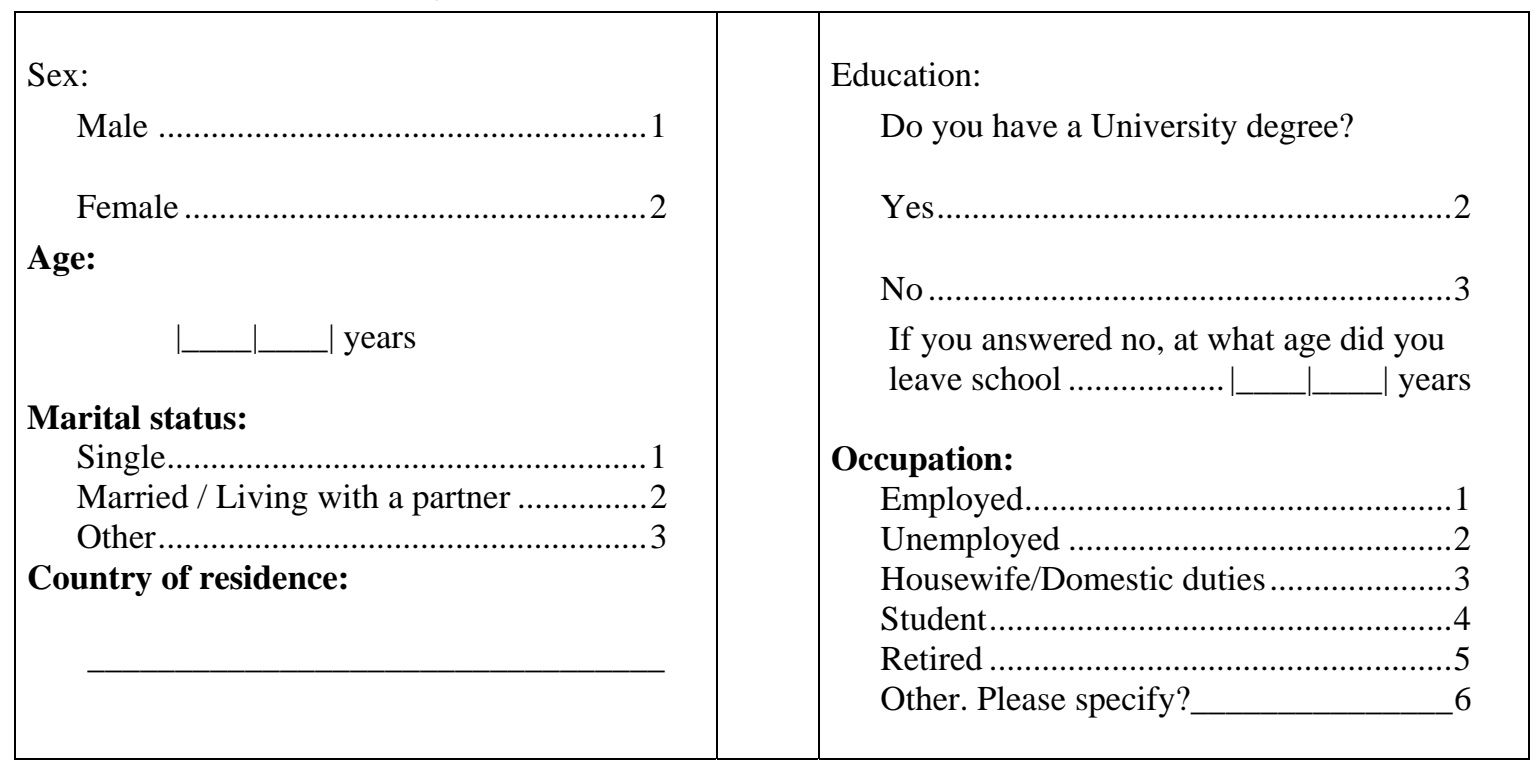

Profession (past or present)? (to show card 1)

a) Member of parliament, Senior civil servant, Director or Senior company executive.......1

b) Senior professional (eg. Doctor, Lawyer, University teacher, Scientist, Artist, etc.) ......2

c) Junior professional (eg. Nurse, School teacher, Junior civil servant, Policeman,

Entertainer, etc.) 
d) Member of your country's armed forces (army, navy, air force)

e) Office worker (eg. Clerk, Banker, Travel Agent, Secretary, Receptionist, etc.) ..............5

f) Skilled worker (eg. Foreman, Electrician, Tradesman, Technician, etc.) ........................6

g) Semi-skilled worker (eg. Machinist, Driver, Apprentice, Waiter, etc.) ............................7

h) Other manual worker (eg. Cleaner, Labourer, Construction worker, etc.) .......................8

i) Farm labourer

j) Other. Please specify: 10

Do you have family living, or with roots in the Azores?
a) Yes .............. 1
b) No .............. 2

\section{Part - Trip Details}

Q1 - What was the primary purpose of this trip? (Mark one answer only.) (to show card 2)
a) Vacation/pleasure 1
b) Visiting friends or relatives ................................................................. 2
c) Business/work (meetings, conventions, conferences, trade fairs, etc.) .... 3
d) Cultural/sporting events ........................................................................ 4
e) Other. Please specify: _ 5

Q2 - Have you visited the Azores before? (Mark one answer only.)
a) No 1
b) Yes, once .................................... 2
c) Yes, more than once .................... 3

Q3 - Did you consider alternative destinations before coming to the Azores? (Mark one answer only.)
a) No .1
b) Yes. Which? 2

Q4 - Which islands did you visit and where did you stay? (to show card 3)

\begin{tabular}{|c|c|c|c|c|c|c|c|c|}
\hline \multicolumn{2}{|c|}{ Islands visited } & \multicolumn{2}{|c|}{ Time spent on the island } & \multicolumn{3}{|c|}{ Types of accommodation } & \multirow[b]{2}{*}{$\begin{array}{l}\text { Friends/ } \\
\text { relatives }\end{array}$} & \multirow[b]{2}{*}{$\begin{array}{r}\text { Other } \\
\text { type }\end{array}$} \\
\hline & & $\mathrm{N}^{\circ}$ of nights & $\begin{array}{l}\text { Less than } 1 \text { day } \\
\text { spent }\end{array}$ & Hotel & $\begin{array}{c}\text { Pensão/ } \\
\text { Residencial }\end{array}$ & $\begin{array}{c}\text { Rural } \\
\text { accommodation }\end{array}$ & & \\
\hline Santa Maria & 1 & |_ & 1 & 1 & 2 & 3 & 4 & 5 \\
\hline S. Miguel & 2 & | & 1 & 1 & 2 & 3 & 4 & 5 \\
\hline Terceira & 3 & 1 & 1 & 1 & 2 & 3 & 4 & 5 \\
\hline S. Jorge & 4 & 1 & 1 & 1 & 2 & 3 & 4 & 5 \\
\hline Graciosa & 5 & 1 & 1 & 1 & 2 & 3 & 4 & 5 \\
\hline Pico & 6 & 1 & 1 & 1 & 2 & 3 & 4 & 5 \\
\hline Faial & 7 & __ & 1 & 1 & 2 & 3 & 4 & 5 \\
\hline Flores & 8 & _ & 1 & 1 & 2 & 3 & 4 & 5 \\
\hline Corvo & 9 & _ & 1 & 1 & 2 & 3 & 4 & 5 \\
\hline
\end{tabular}

Q5 - Who was your principal travel companion(s) on this trip to the Azores? (Mark one answer only.) (to show card 4)
a) I came alone .1
b) Spouse/partner ............................... 2
c) Group of adults ........................... 3 
d) Family with children

.4

e) Business/work associate(s) ..........5

\section{Part - Attributes of destination choice}

Q6 - How important was each of the following factors when you made your choice of the Azores as a holiday destination?

(Mark one answer only for each factor.) (to show card 5)

Importance scale

\begin{tabular}{|c|c|c|c|c|c|}
\hline & $\begin{array}{l}\text { Very low } \\
\text { importanCE }\end{array}$ & $\begin{array}{c}\text { Low } \\
\text { importance }\end{array}$ & $\begin{array}{l}\text { Average } \\
\text { importance }\end{array}$ & $\begin{array}{c}\text { High } \\
\text { importance }\end{array}$ & $\begin{array}{l}\text { Very high } \\
\text { importance }\end{array}$ \\
\hline $\begin{array}{l}\text { a) Originality/uniqueness of destination } \\
\text { (natural and cultural features) }\end{array}$ & 1 & 2 & 3 & 4 & 5 \\
\hline b) Isolation/remoteness of the region & 1 & 2 & 3 & 4 & 5 \\
\hline c) Climate & 1 & 2 & 3 & 4 & 5 \\
\hline d) Accessibility of the Azores & 1 & 2 & 3 & 4 & 5 \\
\hline e) Package tours & 1 & 2 & 3 & 4 & 5 \\
\hline f) Available information & 1 & 2 & 3 & 4 & 5 \\
\hline $\begin{array}{l}\text { g) Availability/quality of } \\
\text { accommodation }\end{array}$ & 1 & 2 & 3 & 4 & 5 \\
\hline $\begin{array}{l}\text { h) Availability/quality of local } \\
\text { transportation }\end{array}$ & 1 & 2 & 3 & 4 & 5 \\
\hline i) Contact with friends and relatives & 1 & 2 & 3 & 4 & 5 \\
\hline j) Value for money & 1 & 2 & 3 & 4 & 5 \\
\hline I) Quality of service & 1 & 2 & 3 & 4 & 5 \\
\hline $\begin{array}{l}\text { m) Sports facilities and activities (golf, } \\
\text { tennis, etc.) }\end{array}$ & 1 & 2 & 3 & 4 & 5 \\
\hline n) Scenery, landscape & 1 & 2 & 3 & 4 & 5 \\
\hline o) Gastronomy & 1 & 2 & 3 & 4 & 5 \\
\hline p) Entertainment, night life & 1 & 2 & 3 & 4 & 5 \\
\hline $\begin{array}{l}\text { q) Historic and architectural heritage, } \\
\text { monuments, museums }\end{array}$ & 1 & 2 & 3 & 4 & 5 \\
\hline $\begin{array}{l}\text { r) Nature, fauna and flora, volcanic } \\
\text { nature of the islands }\end{array}$ & 1 & 2 & 3 & 4 & 5 \\
\hline $\begin{array}{l}\text { s) Cultural attractions, festivals, special } \\
\text { events }\end{array}$ & 1 & 2 & 3 & 4 & 5 \\
\hline $\begin{array}{l}\text { t) Ocean, beaches and other water } \\
\text { activities }\end{array}$ & 1 & 2 & 3 & 4 & 5 \\
\hline u) Religious attractions, religious events & 1 & 2 & 3 & 4 & 5 \\
\hline v) Shopping facilities & 1 & 2 & 3 & 4 & 5 \\
\hline $\begin{array}{l}\text { x) Hospitality/friendliness of the local } \\
\text { people }\end{array}$ & 1 & 2 & 3 & 4 & 5 \\
\hline z) Peacefulness, tranquillity, pace of life & 1 & 2 & 3 & 4 & 5 \\
\hline aa) Safety and security & 1 & 2 & 3 & 4 & 5 \\
\hline ab) Activities for families with children & 1 & 2 & 3 & 4 & 5 \\
\hline
\end{tabular}




\section{Destination performance and tourist satisfaction}

Q7 - Now that your holiday is nearly finished, please indicate how satisfied you are with each of the following factors:

(Mark one answer only for each factor.) (to show card 6)

Satisfaction scale

\begin{tabular}{|c|c|c|c|c|c|}
\hline & $\begin{array}{l}\text { Very low } \\
\text { satisfaction }\end{array}$ & $\begin{array}{c}\text { Low } \\
\text { satisfaction }\end{array}$ & $\begin{array}{c}\text { Average } \\
\text { satisfaction }\end{array}$ & $\begin{array}{c}\text { High } \\
\text { satisfaction }\end{array}$ & $\begin{array}{l}\text { Very high } \\
\text { satisfaction }\end{array}$ \\
\hline $\begin{array}{l}\text { a) Originality/uniqueness of destination } \\
\text { (natural and cultural features) }\end{array}$ & 1 & 2 & 3 & 4 & 5 \\
\hline b) Isolation/remoteness of the region & 1 & 2 & 3 & 4 & 5 \\
\hline c) Climate & 1 & 2 & 3 & 4 & 5 \\
\hline d) Accessibility of the Azores & 1 & 2 & 3 & 4 & 5 \\
\hline e) Package tours & 1 & 2 & 3 & 4 & 5 \\
\hline f) Available information & 1 & 2 & 3 & 4 & 5 \\
\hline g) Availability/quality of accommodation & 1 & 2 & 3 & 4 & 5 \\
\hline $\begin{array}{l}\text { h) Availability/quality of local } \\
\text { transportation }\end{array}$ & 1 & 2 & 3 & 4 & 5 \\
\hline i) Contact with friends and relatives & 1 & 2 & 3 & 4 & 5 \\
\hline j) Value for money & 1 & 2 & 3 & 4 & 5 \\
\hline l) Quality of service & 1 & 2 & 3 & 4 & 5 \\
\hline $\begin{array}{l}\text { m) Sports facilities and activities (golf, } \\
\text { tennis, etc.) }\end{array}$ & 1 & 2 & 3 & 4 & 5 \\
\hline n) Scenery, landscape & 1 & 2 & 3 & 4 & 5 \\
\hline o) Gastronomy & 1 & 2 & 3 & 4 & 5 \\
\hline p) Entertainment, night life & 1 & 2 & 3 & 4 & 5 \\
\hline $\begin{array}{l}\text { q) Historic and architectural heritage, } \\
\text { monuments, museums }\end{array}$ & 1 & 2 & 3 & 4 & 5 \\
\hline $\begin{array}{l}\text { r) Nature, fauna and flora, volcanic nature } \\
\text { of the islands }\end{array}$ & 1 & 2 & 3 & 4 & 5 \\
\hline $\begin{array}{l}\text { s) Cultural attractions, festivals, special } \\
\text { events }\end{array}$ & 1 & 2 & 3 & 4 & 5 \\
\hline $\begin{array}{l}\text { t) Ocean, beaches and other water } \\
\text { activities }\end{array}$ & 1 & 2 & 3 & 4 & 5 \\
\hline u) Religious attractions, religious events & 1 & 2 & 3 & 4 & 5 \\
\hline v) Shopping facilities & 1 & 2 & 3 & 4 & 5 \\
\hline $\begin{array}{l}\text { x) Hospitality/friendliness of the local } \\
\text { people }\end{array}$ & 1 & 2 & 3 & 4 & 5 \\
\hline z) Peacefulness, tranquillity, pace of life & 1 & 2 & 3 & 4 & 5 \\
\hline aa) Safety and security & 1 & 2 & 3 & 4 & 5 \\
\hline ab) Activities for families with children & 1 & 2 & 3 & 4 & 5 \\
\hline
\end{tabular}


IV PARTE - Sustainable practices in the tourism industry

Q8 - How important do you think each of the following factors is for holiday-makers to have a high quality holiday?

(Mark one answer only for each factor.) (to show card 7)

\begin{tabular}{|c|c|c|c|c|c|}
\hline & \begin{tabular}{|c|} 
Very low \\
importance
\end{tabular} & \begin{tabular}{c|c|} 
Low \\
importance
\end{tabular} & \begin{tabular}{c|} 
Average \\
importance
\end{tabular} & $\begin{array}{c}\text { High } \\
\text { importance }\end{array}$ & $\begin{array}{l}\text { Very high } \\
\text { importance }\end{array}$ \\
\hline $\begin{array}{l}\text { a) Separating recyclable or re-usable materials } \\
\text { from other solid waste }\end{array}$ & 1 & 2 & 3 & 4 & 5 \\
\hline $\begin{array}{l}\text { b) Re-using materials and containers to reduce } \\
\text { solid waste }\end{array}$ & 1 & 2 & 3 & 4 & 5 \\
\hline $\begin{array}{l}\text { c) Adequate treatment and disposition of solid } \\
\text { waste }\end{array}$ & 1 & 2 & 3 & 4 & 5 \\
\hline d) Reducing energy and fuel consumption & 1 & 2 & 3 & 4 & 5 \\
\hline e) Using energy efficient technologies & 1 & 2 & 3 & 4 & 5 \\
\hline $\begin{array}{l}\text { f) Using alternative/renewable energy sources } \\
\text { (solar, photovoltaic) }\end{array}$ & 1 & 2 & 3 & 4 & 5 \\
\hline g) Conserving water & 1 & 2 & 3 & 4 & 5 \\
\hline $\begin{array}{l}\text { h) Using undrinkable water when possible (for } \\
\text { irrigation, laundry, etc.) }\end{array}$ & 1 & 2 & 3 & 4 & 5 \\
\hline i) Adequate sewage treatment & 1 & 2 & 3 & 4 & 5 \\
\hline j) Using environmentally friendly products & 1 & 2 & 3 & 4 & 5 \\
\hline l) Using recycled material where possible & 1 & 2 & 3 & 4 & 5 \\
\hline $\begin{array}{l}\text { m) Substituting hazardous materials with } \\
\text { environmentally preferable alternatives }\end{array}$ & 1 & 2 & 3 & 4 & 5 \\
\hline $\begin{array}{l}\text { n) Reducing noise (improving sound insulation } \\
\text { levels, etc.) }\end{array}$ & 1 & 2 & 3 & 4 & 5 \\
\hline o) Monitoring/reducing external air emissions & 1 & 2 & 3 & 4 & 5 \\
\hline p) Purchasing local products when available & 1 & 2 & 3 & 4 & 5 \\
\hline $\begin{array}{l}\text { q) Educating and training staff to meet these } \\
\text { sustainable practices }\end{array}$ & 1 & 2 & 3 & 4 & 5 \\
\hline r) Employing local people and building materials & 1 & 2 & 3 & 4 & 5 \\
\hline s) Creating non-smoking areas and rooms & 1 & 2 & 3 & 4 & 5 \\
\hline $\begin{array}{l}\text { t) Encouraging guests to adopt water and energy } \\
\text { reduction practices (to re-use bathroom linen, etc.) }\end{array}$ & 1 & 2 & 3 & 4 & 5 \\
\hline u) Providing environmental guidelines for tourists & 1 & 2 & 3 & 4 & 5 \\
\hline v) Motivating tourists to use public transportation & 1 & 2 & 3 & 4 & 5 \\
\hline $\begin{array}{l}\text { x) Informing tourists about the local attractions } \\
\text { (natural and cultural) }\end{array}$ & 1 & 2 & 3 & 4 & 5 \\
\hline z) Implementing quality management systems & 1 & 2 & 3 & 4 & 5 \\
\hline $\begin{array}{l}\text { aa) Introducing ecolabels, to indicate tourist } \\
\text { facilities and sites using environmental } \\
\text { management systems successfully }\end{array}$ & 1 & 2 & 3 & 4 & 5 \\
\hline
\end{tabular}


Q9 - What would bring you back to the Azores outside of the summer season?

Q10 - Were there any activities that you expected to find on the islands that were not available?
a) No.
1
b) Yes. Which? 2

Q11 - Do you think you will return to the Azores?
a) Yes ..........1
b) No ............2

Q12 - Would you recommend a visit to the Azores to others?
a) Yes 1
b) No ............2

Q13 - Rate your overall satisfaction of your visit to the Azores: (Mark one answer only.)
a) Very satisfied 5
b) Satisfied 4
c) Neither dissatisfied nor satisfied ..3
d) Dissatisfied .2
e) Very dissatisfied. 1 